Article

\title{
Perspectives on Cultural and Sustainable Rural Tourism in a Smart Region: The Case Study of Marmilla in Sardinia (Italy)
}

\section{Chiara Garau}

Department of Civil and Environmental Engineering and Architecture, DICAAR, University of Cagliari, via Santa Croce, 67, Cagliari 09124, Italy; E-Mail: cgarau@unica.it; Tel.: +39-070-675-5371

Academic Editor: Victor T. King

Received: 10 March 2015 / Accepted: 7 May 2015 / Published: 26 May 2015

\begin{abstract}
This paper is being inserted into the current debate on the topic of sustainability, as it applies to rural tourism. In particular, it addresses the need to identify strategic actions that will enhance the dissemination of cultural resources to facilitate cultural planning. Balancing the dynamic tension that characterizes the relationship between tourism development and protection of the landscape is key to finalizing appropriate planning strategies and actions, especially in the context of marginal rural areas. In support of theoretical and methodological reflections pertinent to this relationship, this paper presents a case study of the region of Marmilla on Italy's island of Sardinia. The absence of both a "cultural planning" philosophy and a strategic approach to systemic and sustainable rural tourism in this country has been acknowledged. This paper concludes by discussing the results that emerged during the preparation of this case study, with respect to smart, sustainable, rural tourism development, while accepting the need for compromises between the force of globalization, nature, tourism, places, and people.
\end{abstract}

Keywords: cultural tourism; rural tourism; sustainable tourism; smart land use; cultural planning; Sardinia

\section{Introduction}

The phenomenon of rural tourism has recently assumed new significance, having risen gradually from a marginal to a widespread practice. Changes to the European countryside, increasing globalization, and growing competition between traditional locations and new destinations have raised tourist expectations, encouraging travel to places less well known, and recalling, for this reason, those 
tourist flows attracted by the authenticity of the experiences visitors are likely to have [1-4]. The pursuit of authenticity - consisting of cultural and social identities, traditions, memories, intangible connections, local peculiarities, and rural landscapes - has therefore led communities and local, national, and European governments [5] to respond to new tourism demands in more complex ways [6].

In Europe, this phenomenon has been consolidated over time, beginning in the late eighties. Since then, the literature has documented a wide range of theoretical paradigms aimed at interpreting these consequences, and the natural environment has seen the emergence of rural tourism. One of the first definitions of rural tourism was proposed by the European Commission in 1986: "Rural tourism is a broad concept that includes not only farm tourism or agritourism-accommodation provided by farmers - but all tourist activities in rural areas" [7]. Simonicca (1997) interpreted rural tourism as an alternative type of tourism with sustainable objectives [8]. Namely, socio-cultural or natural rural tourism environments represent alternatives to the places where tourists live, and they in turn try to experience positive and educational impacts from having visited them [9]. Daugstag (2008) defined the discovery of the rural land as "a refuge from urban life" [10]. That is, it represents an alternative to embracing globalization. Barke (2004) argued that rural tourism had developed in response to two factors. These were the "decline of traditional rural activities, principally agriculture and the consequent demographic changes, especially depopulation," and "the perceived need to diversify the [...] tourism product away from traditional mass beach tourism characteristic of the 1960s and 1970s" [11]. During that period, the phenomenon that Henry Lefebre called "the right to the city" [12] was tangible: the population had moved from rural areas to cities, mainly because the city provided the civitas, namely the social ties, functions, and services capable of providing an urban lifestyle. These conditions can occur in areas with small populations.

In the nineties, the population increased, as did the volume of information. Competitive territorial marketing strategies began to appear. They were aimed not only at improving the performance and increasing the attractiveness of the land, but also at maximizing its long-term economic benefits; they were also designed to ensure the sustainability of the territory, through proper management of tourist flows. Especially for rural areas, different forms of place-based enhancements such as eco-museums, farms, community maps (or parish maps), educational farms, and educational tours increased.

Corner and Swarbrooke (2004) emphasized the two main outcomes offered by rural tourism: farm hosting, in which country homes were used to provide hospitality, and farm holidays, during which the tourist was placed in rural areas and participated actively in the rural lifestyle that had been preserved as a primary agricultural activity [13].

Cawley and Gillmor (2008) argued that we could speak of rural tourism when there were strong links with the land's economic and productive activities, and three main features were in evidence: integration, sustainability, and endogeneity [14]. Schubert (2006), on the other hand, believed that rural tourism represented a key strategy for regional development [15]. Zhou (2014) asserted that rural tourism was by nature mainly "domestic, and positioned as a small-scale activity" [16], and Balestrieri (2005) highlighted the versatility of rural tourism, and suggested that it was for this reason that it was able to "play the role of engine of sustainable economic development" [17]. In sum, the rural landscape brought environmental sustainability together with different social, cultural, and economic components, due to its different, content-rich, inter-connected, and integrated attractors, along with its 
strong anthropological characteristics, because it related to the culture and lifestyles of settled communities, and thereby enabled planning for tourism.

In view of global economic dynamics, planning and programming for the development of sustainable rural tourism represents one of the new challenges for strengthening and revitalizing lands that are otherwise not competitive. This paper begins by defining rural tourism as it has become established in Italy during the last ten years. Then, a case study of the region of Marmilla in Sardinia, Italy is presented. The author elaborates on a process for establishing a sustainable rural tourist destination, and describes the necessary cultural changes required of the different actors and tourist enterprises that would be involved in this process. It is assumed that Marmilla is a model of tourism development, and demonstrates best practices for rural cultural tourism, based on recent "smart region" paradigms [18,19], "Neogeography" [20,21], and the development of computing platforms that are increasingly more integrated and interactive [22]. Finally, sustainable rural tourism is discussed, using the study's findings. The paper concludes by recommending the development of smart rural-urban linkages, and demonstrating how even the planning and programming of rural tourism cannot escape comparisons with sustainability, which should be seen not as a constraint, but as a goal of contemporary management and place-based marketing.

\section{Sustainable Rural Tourism in Italy: Some Reference Data}

Although tourism was one of Italy's most dynamic economic sectors in the recession period [23], the tourist presence has fluctuated in recent years. In fact, Italy's tourism sector data have shown a greater loss of market share than those recorded by other direct competitors such as Spain and France [24]. There are various reasons for this decrease: unstructured governance, fragmentary promotions abroad [25], a lack of engagement by the National Agency of Tourism [26], the Italian economic tourism sector being composed predominantly of small and medium-sized businesses [27], the lack of competitive tourism products, poor infrastructure, and a general lack of coordination at the political, technical, and operational decision-making levels [28]. In addition, there are problematic aspects related to the use of digital platforms, such as the lack of a digital tourism strategy, and the insufficient use of digital sales channels and applications for smartphones and tablets. To address these weaknesses, the Strategic Plan for the Development of Tourism in Italy (Piano strategico per lo sviluppo del turismo in Italia (2013)) identifies targeted and specific actions that are to be undertaken: the construction of a laboratory for e-tourism; the development of mobile applications specifically targeted at foreign tourists, who know how to integrate logistical information with cultural resources (such as museums and exhibitions); the definition of roles and responsibilities; and the coordination of governance arrangements, not only between the state and the regions/provinces, but also between provinces and municipalities [29]. Service integration, mobile applications, and the coordination of decision making at all levels are key aspects of national tourism innovations, and they need to be relaunched in a smart way.

These factors have also been of interest in rural areas, where they have produced different results. In these areas, in fact, there have been positive trends, especially from 2003-2013. Although there have been no ad hoc surveys on the phenomenon, and although there are objective difficulties involved in identifying a destination's unique rural character [30], this trend toward a rural tourism sector is apparent from the consistent growth of agritourism farms. 
As shown in Table 1, their number rose from 13,019 in 2003, to 20,897 in 2013, thereby increasing by $60.5 \%$. Firms dedicated to other agritourism activities have acquired an important role. They have shown increases of $47.9 \%$ and $62.7 \%$ for tasting and other activities respectively. In the same period, the beds available have increased by 94,738, and the seating capacity has increased by 157,615 [31]. The major "boom" in 2013, however, concerned activities related to "educational farms", which, compared to 2010 - the year they began to appear-have increased by $15 \%$. While central Italy offers agritourism farms with greater diversification (Table 2), in the period between 2012 and 2013, agritourism farms grew more significantly in the north at $6.1 \%$, relative to those in the center and on the islands; in the south, a decline of 5.8\% was observed (Table 3) [31]. The regions of Tuscany and Trentino Alto Adige have the most agritourism farms (in 2013 they exceeded 3500 units). Agricultural hospitality is more rooted there for historical reasons. Agritourism farms are also widespread in the regions of Lombardy, Veneto, Umbria, Piedmont, and Emilia Romagna (with over 1000 companies), and, finally, Lazio, Marche, and Sardinia.

Although the data described above tend to underestimate the phenomenon [32], they confirm that rural tourism is a reality with its own identity, and a well-characterized question. Interest in this sector is destined to grow, probably, as mentioned in the previous paragraph, due to evolving tourism preferences and demands. A large part of rural Italian tourism is still very much influenced by several factors, including the fragmentation and lack of cohesion of the valorization choices in an extensive rural area; local communities' disinclination to accept change, being too weak to assume the stresses that accompany innovative tourism; and the fairly limited capacities of existing hospitality structures.

Linking rural tourism with cultural tourism can lead to the integration and diversification of tourism opportunities, and translate the tourist destination as a whole into a competitive destination. In fact, the combination of cultural and rural offerings are able to support political, institutional, or proactive choices for new tourism products, and may represent a unique experience [3,4], not only for the tourist in search of authenticity, but also for all other stakeholders (the local communities, local administrators, institutions, non-profit organizations, and business employees) involved in the territory. Rurality, widespread cultural heritage, and tourism therefore comprise a complex relationship that imposes on territories and local actors the expectation that they will clarify their tourism potential, and the related processes already in place. In this way, the rural area is no longer a "product", but is rather a place where sustainable place-based integrated development processes are activated [33].

Sardinia was chosen for this study for several reasons. First, this island's rural tourism processes have never before been considered as offering an alternative, more consolidated development model relative to the seaside model. Rural tourism has always been regarded as secondary to seaside tourism. The development of a rural development model, however, could facilitate the attenuation of Sardinia's imbalances by countering the seasonal ebbs and flows characteristic of seaside tourism. Secondly, Sardinia ranks eleventh in the total number of Italian farms by region, and represents the median number of farms (Table 3). For these reasons, Sardinia is considered to be representative of the rural Italian reality. This case study of the natural region of Marmilla in Sardinia also addresses questions associated with integrating the cultural, natural, and rural heritage. Even though the Marmilla region has this significant potential, a strategic process for tourism planning has not yet been created. In this paper, based on the following concepts: tourism, rurality, and cultural heritage, the author defines the conditions needed to initiate a process of reflection that could lead to defining a strategic tourism planning process. 
Table 1. Typologies of agritourism farms in Italy (ISTAT Data, 2014).

\begin{tabular}{|c|c|c|c|c|c|c|c|c|c|c|c|c|c|}
\hline \multirow{2}{*}{$\begin{array}{l}\text { Typologies of } \\
\text { agritourism farms }\end{array}$} & \multirow[b]{2}{*}{2003} & \multirow[b]{2}{*}{2004} & \multirow[b]{2}{*}{2005} & \multirow[b]{2}{*}{2006} & \multirow[b]{2}{*}{2007} & \multirow[b]{2}{*}{2008} & \multirow[b]{2}{*}{2009} & \multirow[b]{2}{*}{2010} & \multirow[b]{2}{*}{2011} & \multirow[b]{2}{*}{2012} & \multirow[b]{2}{*}{2013} & \multicolumn{2}{|c|}{ Difference 2003-2013 } \\
\hline & & & & & & & & & & & & $\begin{array}{c}\text { Absolute } \\
\text { Number (Abs.) }\end{array}$ & $\%$ \\
\hline \multicolumn{14}{|l|}{ Accommodation } \\
\hline - Firms & 10,767 & 11,575 & 12,593 & 13,854 & 14,822 & 15,334 & 15,681 & 16,504 & 16,759 & 16,906 & 17,102 & 6335 & 58.8 \\
\hline - Number of beds & 130,195 & 140,685 & 150,856 & 167,087 & 179,985 & 189,013 & 193,480 & 206,145 & 210,747 & 217,946 & 224,933 & 94,738 & 72.8 \\
\hline - Picnic areas & 4540 & 5386 & 5826 & 6935 & 7055 & 7320 & 7785 & 8759 & 9113 & 8363 & 8180 & 3640 & 80.2 \\
\hline \multicolumn{14}{|l|}{ Food \& beverage } \\
\hline - Firms & 6193 & 6833 & 7201 & 7898 & 8516 & 8928 & 9335 & 9914 & 10,033 & 10,144 & 10,514 & 4321 & 69.8 \\
\hline - Seating capacity & 249,342 & 266,654 & 277,866 & 298,003 & 322,145 & 337,385 & 365,943 & 385,470 & 385,075 & 397,175 & 406,957 & 157,615 & 63.2 \\
\hline \multicolumn{14}{|l|}{ Tasting } \\
\hline - Firms & 2426 & 2737 & 2542 & 2664 & 3224 & 3304 & 3400 & 3836 & 3876 & 3449 & 3588 & 1162 & 47.9 \\
\hline \multicolumn{14}{|l|}{ Other Activities } \\
\hline \multicolumn{13}{|l|}{ of which } & 62.7 \\
\hline - Horse Riding & 1364 & 1494 & 1478 & 1557 & 1559 & 1615 & 1548 & 1638 & 1662 & 1489 & 1230 & -134 & -9.8 \\
\hline - Escursionism & 2452 & 2692 & 2981 & 3131 & 2879 & 3140 & 3071 & 3190 & 3233 & 3324 & 3124 & 672 & 27.4 \\
\hline - Naturalistic Obs. & 224 & 265 & 575 & 517 & 558 & 607 & 623 & 784 & 891 & 932 & 972 & 748 & 333.9 \\
\hline - Trekking & 1350 & 1463 & 1426 & 1465 & 1629 & 1657 & 1674 & 1950 & 1949 & 1821 & 1717 & 367 & 27.2 \\
\hline - Mountain Bike & 2101 & 2422 & 2258 & 2311 & 2347 & 2398 & 2309 & 2800 & 2794 & 2785 & 2851 & 750 & 35.7 \\
\hline - Educational Farms & - & - & - & - & - & - & - & 752 & 1122 & 1251 & 1176 & 1176 & - \\
\hline - Courses & 693 & 812 & 942 & 1025 & 1256 & 1407 & 974 & 1967 & 1878 & 2009 & 1770 & 1077 & 155.4 \\
\hline - Sports & 2927 & 3006 & 3474 & 3682 & 3758 & 4203 & 4168 & 4152 & 4141 & 5058 & 5088 & 2161 & 73.8 \\
\hline - Various & 3786 & 4003 & 4288 & 5043 & 5395 & 5616 & 5994 & 6312 & 6737 & 4917 & 6033 & 2247 & 59.4 \\
\hline \multicolumn{14}{|l|}{ Agritourism Farms } \\
\hline - Total Firms & 13,019 & 14,017 & 15,327 & 16,765 & 17,720 & 18,480 & 19,019 & 19,973 & 20,413 & 20,474 & 20,897 & 7878 & 60.5 \\
\hline
\end{tabular}


Table 2. Agritourism farms in Italy by type of activity and region (ISTAT Data, 2014).

\begin{tabular}{|c|c|c|c|c|c|c|c|c|c|c|c|c|}
\hline \multirow{3}{*}{$\begin{array}{l}\text { Regions } \\
\text { Geographical } \\
\text { distributions }\end{array}$} & \multicolumn{4}{|c|}{ Food \& beverages } & \multicolumn{4}{|c|}{ Tasting } & \multicolumn{4}{|c|}{ Other Activities } \\
\hline & \multirow{2}{*}{2012} & \multirow{2}{*}{2013} & \multicolumn{2}{|c|}{ Difference } & \multirow{2}{*}{2012} & \multirow{2}{*}{2013} & \multicolumn{2}{|c|}{ Difference } & \multirow{2}{*}{2012} & \multirow{2}{*}{2013} & \multicolumn{2}{|c|}{ Difference } \\
\hline & & & Abs. & $\%$ & & & Abs. & $\%$ & & & Abs. & $\%$ \\
\hline Piedmont & 753 & 790 & 37 & 4.9 & 589 & 616 & 27 & 4.6 & 902 & 925 & 23 & 2.5 \\
\hline Aosta Valley & 45 & 36 & -9 & -20.0 & 35 & 9 & -26 & -74.3 & 10 & 9 & -1 & -10.0 \\
\hline Lombardy & 1019 & 1060 & 41 & 4.0 & 116 & 144 & 28 & 24.1 & 673 & 722 & 49 & 7.3 \\
\hline Trentino-Alto Adige & 577 & 625 & 48 & 8.3 & 100 & 108 & 8 & 8.0 & 1311 & 1348 & 37 & 2.8 \\
\hline Bolzano-Bozen & 430 & 470 & 40 & 9.3 & - & - & - & - & 1255 & 1,292 & 37 & 2.9 \\
\hline Trento & 147 & 155 & 8 & 5.4 & 100 & 108 & 8 & 8.0 & 56 & 56 & - & - \\
\hline Veneto & 756 & 782 & 26 & 3.4 & 601 & 641 & 40 & 6.7 & 511 & 524 & 13 & 2.5 \\
\hline Friuli-Venezia Giulia & 447 & 454 & 7 & 1.6 & 10 & 13 & 3 & 30.0 & 229 & 240 & 11 & 4.8 \\
\hline Liguria & 281 & 353 & 72 & 25.6 & - & 40 & 40 & - & 336 & 287 & -49 & -14.6 \\
\hline Emilia-Romagna & 797 & 834 & 37 & 4.6 & - & - & - & - & 874 & 739 & -135 & -15.4 \\
\hline Tuscany & 1131 & 1232 & 101 & 8.9 & 577 & 515 & -62 & -10.7 & 2925 & 3141 & 216 & 7.4 \\
\hline Umbria & 405 & 409 & 4 & 1.0 & 227 & 237 & 10 & 4.4 & 1108 & 1120 & 12 & 1.1 \\
\hline Marche & 414 & 447 & 33 & 8.0 & 380 & 420 & 40 & 10.5 & 306 & 234 & -72 & -23.5 \\
\hline Lazio & 551 & 596 & 45 & 8.2 & 133 & 162 & 29 & 21.8 & 552 & 571 & 19 & 3.4 \\
\hline Abruzzo & 436 & 410 & -26 & -6.0 & 73 & 56 & -17 & -23.3 & 467 & 377 & -90 & -19.3 \\
\hline Molise & 86 & 86 & - & - & 50 & 50 & - & - & 54 & 54 & - & - \\
\hline Campania & 352 & 396 & 44 & 12.5 & 136 & 151 & 15 & 11.0 & 287 & 330 & 43 & 15.0 \\
\hline Puglia & 271 & 222 & -49 & -18.1 & 146 & 138 & -8 & -5.5 & 231 & 303 & 72 & 31.2 \\
\hline Basilicata & 98 & 78 & -20 & -20.4 & 40 & 20 & -20 & -50.0 & 104 & 54 & -50 & -48.1 \\
\hline Calabria & 569 & 542 & -27 & -4.7 & 50 & 49 & -1 & -2.0 & 503 & 472 & -31 & -6.2 \\
\hline Sicily & 473 & 493 & 20 & 4.2 & 186 & 219 & 33 & 17.7 & 514 & 550 & 36 & 7.0 \\
\hline Sardinia & 683 & 669 & -14 & -2.0 & - & - & - & - & 85 & 96 & 11 & 12.9 \\
\hline ITALY & 10,144 & 10,514 & 370 & 3.6 & 3449 & 3588 & 139 & 4.0 & 11,982 & 12,096 & 114 & 1.0 \\
\hline Northern Italy & 4675 & 4934 & 307 & 6.6 & 1451 & 1571 & 128 & 8.8 & 4846 & 4794 & -15 & -0.3 \\
\hline Central Italy & 2501 & 2684 & 183 & 7.3 & 1317 & 1334 & 17 & 1.3 & 4891 & 5066 & 175 & 3.6 \\
\hline Mezzogiorno & 2968 & 2896 & -27 & -0.9 & 681 & 683 & 31 & 4.6 & 2245 & 2236 & 10 & 0.4 \\
\hline South Italy & 1812 & 1734 & -78 & -4.3 & 495 & 464 & -31 & -6.3 & 1646 & 1590 & -56 & -3.4 \\
\hline Islands & 1156 & 1162 & 6 & 0.5 & 186 & 219 & 33 & 17.7 & 599 & 646 & 47 & 7.8 \\
\hline
\end{tabular}


Table 3. Agritourism farms in Italy by region (ISTAT Data, 2014).

\begin{tabular}{|c|c|c|c|c|c|c|c|c|c|}
\hline \multirow{2}{*}{$\begin{array}{l}\text { Regions } \\
\text { Geographical } \\
\text { distributions }\end{array}$} & \multirow{2}{*}{2012} & \multirow{2}{*}{2013} & \multicolumn{2}{|c|}{ Difference } & \multirow{2}{*}{$\begin{array}{l}\text { Regions } \\
\text { Geographical } \\
\text { distributions }\end{array}$} & \multirow{2}{*}{2012} & \multirow{2}{*}{2013} & \multicolumn{2}{|c|}{ Difference } \\
\hline & & & Abs. & $\%$ & & & & Abs. & $\%$ \\
\hline Piedmont & 1164 & 1220 & 56 & 4.8 & Umbria & 1262 & 1280 & 18 & 1.4 \\
\hline Aosta Valley & 54 & 53 & -1 & -1.9 & Marche & 788 & 880 & 92 & 11.7 \\
\hline Lombardy & 1415 & 1521 & 106 & 7.5 & Lazio & 841 & 884 & 43 & 5.1 \\
\hline Trentino-Alto Adige & 3391 & 3506 & 115 & 3.4 & Abruzzo & 774 & 653 & -121 & -15.6 \\
\hline Bolzano-Bozen & 2996 & 3098 & 102 & 3.4 & Molise & 104 & 104 & - & - \\
\hline Trento & 395 & 408 & 13 & 3.3 & Campania & 407 & 458 & 51 & 12.5 \\
\hline Veneto & 1376 & 1449 & 73 & 5.3 & Puglia & 355 & 353 & -2 & -0.6 \\
\hline Friuli-Venezia Giulia & 588 & 614 & 26 & 4.4 & Basilicata & 145 & 112 & -33 & -22.8 \\
\hline Liguria & 543 & 567 & 24 & 4.4 & Calabria & 610 & 577 & -33 & -5.4 \\
\hline Emilia-Romagna & 1036 & 1106 & 70 & 6.8 & Sicily & 602 & 633 & 31 & 5.1 \\
\hline Tuscany & 4185 & 4108 & -77 & -1.8 & Sardinia & 834 & 819 & -15 & -1.8 \\
\hline ITALY & 20,474 & 20,897 & 423 & 2.1 & Mezzogiorno & 3831 & 3709 & -79 & -2.1 \\
\hline Northern Italy & 9567 & 10,036 & 584 & 6.1 & South Italy & 2395 & 2257 & -138 & -5.8 \\
\hline Central Italy & 7076 & 7152 & 76 & 1.1 & Islands & 1436 & 1452 & 16 & 1.1 \\
\hline
\end{tabular}




\section{Governance and Management of Marmilla's Place-Based Heritage from a Sustainability Perspective}

Based on the preceding information, the question that arises is how to initiate a sustainable tourism approach for an agricultural destination that does not yet have a strategic planning and management approach for its tourism sector. We begin this research by analyzing Marmilla's rural and natural landscape, as well as its cultural and historic heritage. Doing so allows us to understand the extent and value of Marmilla's cultural and environmental aspects. Next, socio-demographic and production supply and demand dynamics are analyzed, to help delineate an appropriate strategic policy for place-based development and tourism planning. Finally, using different scales, the application of direct and indirect governance instruments as they might affect the development of tourism and environmental protection in the Marmilla context are analyzed. These analyses reveal that a successful strategic planning and management approach for Marmilla depends primarily on social capital. Indeed, awareness of local administrators regarding their roles and the potential of a strategic approach to systemic and sustainable rural tourism will provide the conditions needed to improve the attractiveness (and therefore also the place-branding) of the cultural and natural heritage, and make a significant contribution in terms of political cohesion, identity and local development. In this regard, it has been observed that the role of technology can be crucial to the debate on governance for sustainable tourism in rural areas. Indeed, Go, Della Lucia, Trunfio, and Martini (2014) state that there is the need for a link between "two broad knowledge domains, ICTs and place branding [of rural contexts], often isolated from one another" [34]. Tying these two aspects does not delegate to rural areas the characteristic of "sustainable place", but offers them the opportunity to have a voice, visibility and place-based development in the era of globalization [34]. In addition, it captures the need to overcome certain structural limitations, creating, for example, a "system of rural areas": especially in Marmilla, a recent study showed that four of its 18 municipalities (Genuri, Tuili Turri, and Ussarramanna) are at risk of demographic desertification [35].

For this reason, in this paper, with the help of new technologies, the most relevant factors to emerge from previous analyses are identified, collected, and "filtered", using a logical framework, and hypothesizing a scenario aimed at two different but parallel objectives: protecting the natural and cultural heritage, and advancing sustainable tourism development in the case study region of Marmilla, while accepting the need for compromises between the forces of globalization, nature, tourism, places, and people.

\subsection{Case Study of Marmilla}

The region of Marmilla is located in the southern-central part of Sardinia, Italy, in the province of the Middle Campidano (Figure 1). It covers 415 square kilometers, and had a population of 25,619 in 2014 [36].

Marmilla's morphology is mainly devoted to agriculture, supported by a system of small settlements. It comprises 18 municipalities [37] and, as shown in Table 4, is characterized by features typical of southern Italy's inland areas: a low population density, weak economic structures, negative long term demographic trends (Figure 2 and Table 5), and an aging population [38-40]. The social and 
demographic situation is not uniform, and some of the 18 municipalities do not exceed 300 inhabitants (such as Setzu and Las Plassas with 151 and 240 inhabitants respectively), while others have more than 8500 inhabitants (Sanluri). The territory is characterized by a strong reliance on commuting, especially closer to major urban centers such as Cagliari, Oristano, and Sassari.
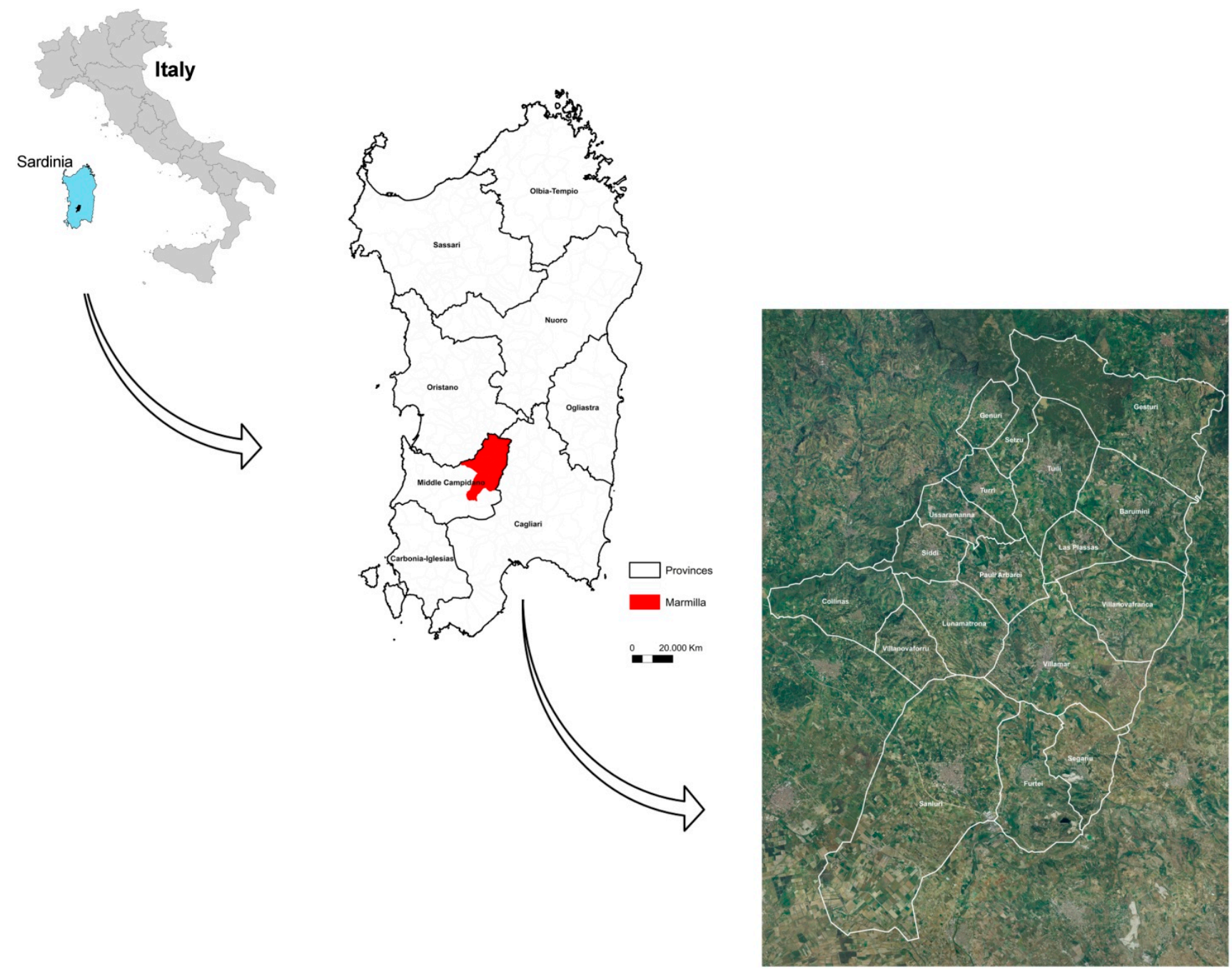

Figure 1. The natural region of Marmilla. 


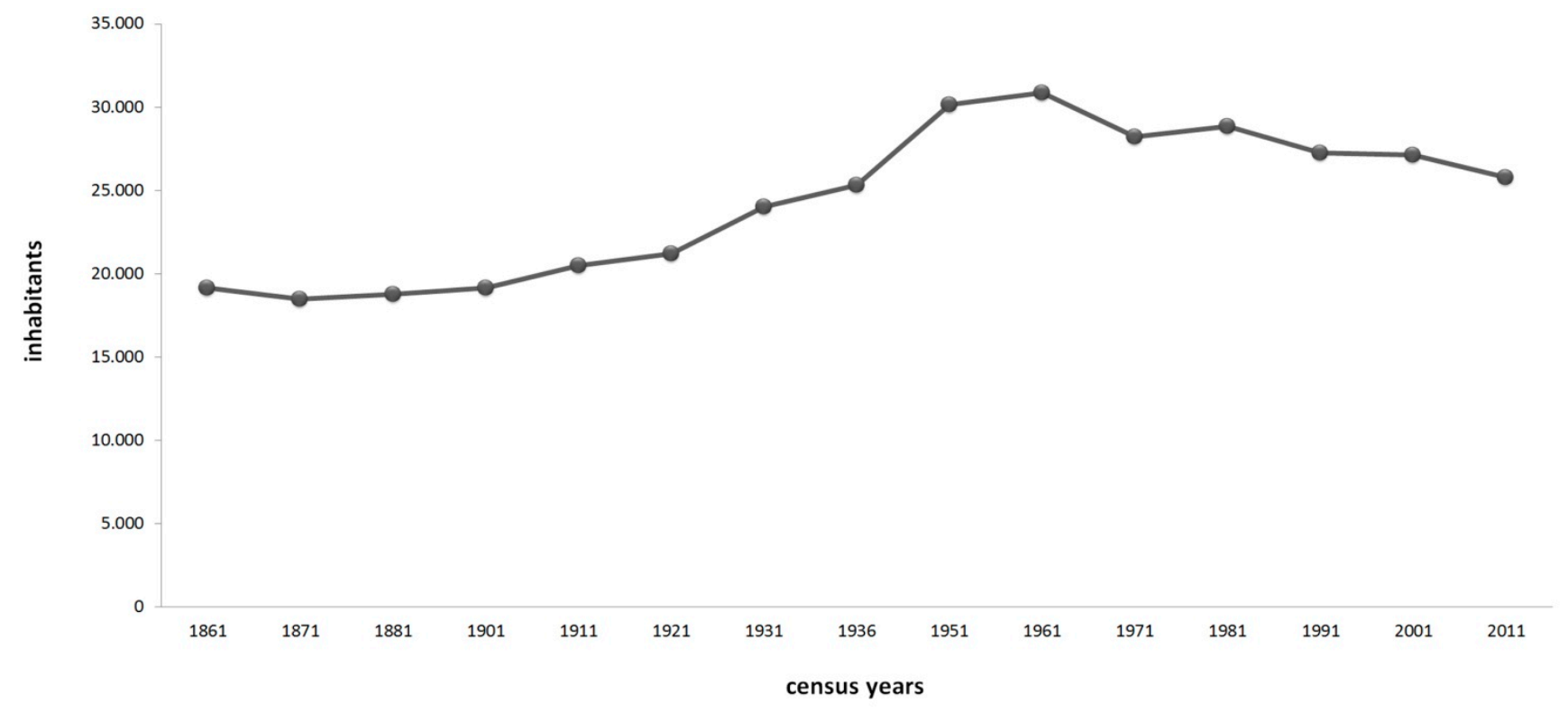

Figure 2. Marmilla's demographic trend from 1861 to 2011 [41].

Table 4. Socio-demographic and economic dynamics in Marmilla [42].

\begin{tabular}{cccccc}
\hline $\begin{array}{c}\text { Geographical } \\
\text { distributions }\end{array}$ & $\begin{array}{c}\text { Area } \\
\text { (km } \\
\text { square) }\end{array}$ & $\begin{array}{c}\text { Population } \\
\text { density (2014) }\end{array}$ & $\begin{array}{c}\text { Population } \\
\mathbf{2 0 1 4} \\
\text { (inhabitants) }\end{array}$ & $\begin{array}{c}\text { Aging } \\
\text { index } \\
\mathbf{2 0 1 4}\end{array}$ & $\begin{array}{c}\text { Disposable Income Per } \\
\text { capita 2013 } \\
\text { (Income-Taxes } \\
\text { [fiscal levy]) }\end{array}$ \\
\hline Barumini & 26.57 & 48.78 & 1296 & 261.4 & $€ 11,986.00$ \\
Collinas & 20.79 & 41.41 & 861 & 292.9 & $€ 12,507.00$ \\
Furtei & 26.12 & 64.20 & 1677 & 204.8 & $€ 11,117.00$ \\
Genuri & 7.55 & 45.03 & 340 & 463.6 & $€ 12,855.00$ \\
Gesturi & 46.87 & 27.29 & 1279 & 319.4 & $€ 10,596.00$ \\
Las Plassas & 11.14 & 22.08 & 246 & 255.6 & $€ 10,596.00$ \\
Lunamatrona & 20.57 & 85.03 & 1749 & 277.7 & $€ 13,028.00$ \\
Pauli Arbarei & 15.12 & 42.72 & 646 & 247.7 & $€ 11,465.00$ \\
Sanluri & 83.78 & 101.81 & 8530 & 174.5 & $€ 14,418.00$ \\
Segariu & 16.69 & 74.18 & 1238 & 206.9 & $€ 10,596.00$ \\
Setzu & 7.82 & 19.31 & 151 & 273.7 & $€ 14,071.00$ \\
Siddi & 11.02 & 61.43 & 677 & 321.2 & $€ 11,291.00$ \\
Tuili & 24.5 & 42.86 & 1050 & 375.5 & $€ 11,986.00$ \\
Turri & 9.64 & 46.37 & 447 & 442.1 & $€ 11,986.00$ \\
Ussaramanna & 9.75 & 57.23 & 558 & 305.0 & $€ 13,376.00$ \\
Villamar & 38.64 & 72.93 & 2818 & 174.0 & $€ 11,465.00$ \\
Villanovaforru & 10.97 & 59.16 & 649 & 272.3 & $€ 11,986.00$ \\
Villanovafranca & 27.46 & 51.24 & 1407 & 283.1 & $€ 10,944.00$ \\
Marmilla & 415 & 61.73 & 25,619 & 226.5 & $€ 12,014.94$ \\
Sardinia & 24,090 & 69.07 & $1,663,859$ & 174.4 & $€ 13,871.00$ \\
Italy & 301,338 & 201.71 & $60,782,668$ & 154.1 & $€ 17,038.20$ \\
\hline
\end{tabular}


Table 5. Marmilla's demographic trend from 1861 to 2011 [41].

\begin{tabular}{|c|c|c|c|c|c|c|c|c|c|c|c|c|c|c|c|}
\hline $\begin{array}{l}\text { Geographical } \\
\text { distributions }\end{array}$ & 1861 & 1871 & 1881 & 1901 & 1911 & 1921 & 1931 & 1936 & 1951 & 1961 & 1971 & 1981 & 1991 & 2001 & 2011 \\
\hline Barumini & 1214 & 1187 & 1221 & 1118 & 1179 & 1335 & 1445 & 1431 & 1685 & 1729 & 1647 & 1516 & 1423 & 1413 & 1310 \\
\hline Collinas & 976 & 1012 & 1072 & 1033 & 1088 & 1065 & 1040 & 1091 & 1206 & 1213 & 1129 & 1145 & 1076 & 1014 & 885 \\
\hline Furtei & 1030 & 915 & 981 & 1057 & 1118 & 1179 & 1280 & 1422 & 1728 & 1846 & 1788 & 1830 & 1729 & 1723 & 1674 \\
\hline Genuri & 359 & 400 & 434 & 383 & 440 & 446 & 535 & 575 & 654 & 706 & 567 & 518 & 444 & 386 & 345 \\
\hline Gesturi & 1660 & 1457 & 1430 & 1431 & 1507 & 1455 & 1643 & 1709 & 1827 & 1801 & 1567 & 1515 & 1438 & 1430 & 1280 \\
\hline Las Plassas & 486 & 459 & 429 & 397 & 454 & 500 & 587 & 502 & 566 & 632 & 379 & 298 & 291 & 269 & 257 \\
\hline Lunamatrona & 968 & 1018 & 1104 & 1148 & 1299 & 1278 & 1467 & 1640 & 1948 & 2017 & 1850 & 1896 & 1896 & 1858 & 1783 \\
\hline Pauli Arbarei & 433 & 424 & 409 & 401 & 477 & 530 & 656 & 676 & 801 & 797 & 787 & 778 & 692 & 720 & 651 \\
\hline Sanluri & 4199 & 4177 & 4177 & 4403 & 4593 & 4786 & 5449 & 5721 & 7555 & 7595 & 7402 & 8305 & 7912 & 8519 & 8460 \\
\hline Segariu & 700 & 588 & 647 & 661 & 732 & 750 & 899 & 989 & 1308 & 1441 & 1409 & 1432 & 1320 & 1358 & 1277 \\
\hline Setzu & 302 & 330 & 276 & 240 & 292 & 267 & 304 & 325 & 278 & 278 & 223 & 223 & 184 & 166 & 144 \\
\hline Siddi & 608 & 615 & 603 & 636 & 631 & 802 & 869 & 871 & 987 & 1121 & 990 & 903 & 869 & 799 & 696 \\
\hline Tuili & 1334 & 1286 & 1242 & 1320 & 1330 & 1302 & 1478 & 1613 & 1713 & 1591 & 1348 & 1347 & 1263 & 1185 & 1062 \\
\hline Turri & 454 & 488 & 511 & 503 & 490 & 487 & 575 & 602 & 729 & 734 & 633 & 597 & 572 & 533 & 442 \\
\hline Ussaramanna & 623 & 640 & 609 & 586 & 677 & 730 & 790 & 863 & 920 & 963 & 835 & 714 & 656 & 611 & 556 \\
\hline Villamar & 1948 & 1825 & 1903 & 2047 & 2250 & 2220 & 2675 & 2876 & 3301 & 3369 & 3057 & 3196 & 3147 & 2960 & 2872 \\
\hline Villanovaforru & 506 & 517 & 593 & 615 & 655 & 709 & 741 & 770 & 905 & 931 & 846 & 789 & 733 & 700 & 681 \\
\hline Villanovafranca & 1356 & 1166 & 1121 & 1189 & 1286 & 1369 & 1577 & 1633 & 2055 & 2117 & 1759 & 1871 & 1621 & 1491 & 1433 \\
\hline Marmilla & 19,156 & 18,504 & 18,762 & 19,168 & 20,498 & 21,210 & 24,010 & 25,309 & 30,166 & 30,881 & 28,216 & 28,873 & 27,266 & 27,135 & 25,808 \\
\hline Sardinia & 609,015 & 636,413 & 680,450 & 795,793 & 868,181 & 885,467 & 983,760 & $1,034,206$ & $1,276,023$ & $1,419,362$ & $1,473,800$ & $1,594,175$ & $1.648,248$ & $1,631,880$ & $1,639,362$ \\
\hline
\end{tabular}


Extensive territories with high environmental quality and low population levels contribute to conserving the land over time, and maintaining its rurality (Figure 3). On the other hand, the region lacks a socially young and dynamic cohort. These issues have become structural problems for place-based development in Marmilla, and have led the Marmilla region to be perceived as being on the margins of Sardinia's economy.

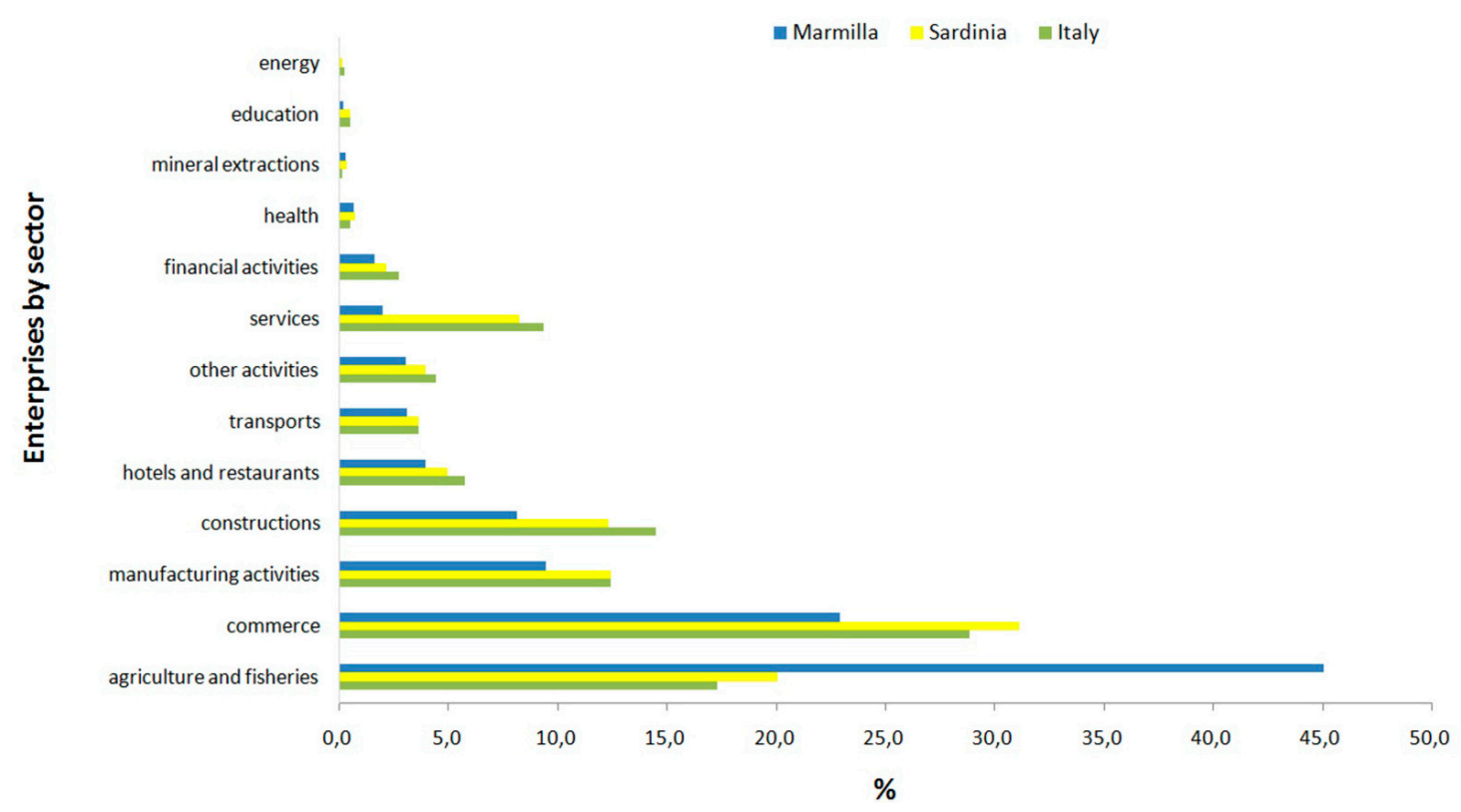

Figure 3. Segmentation by percentage of enterprises (year 2010) [43].

In this context, the development of tourism could limit the impacts of the critical weaknesses described above, by offering new land-based job opportunities to members of the local community, thereby benefitting the entire economy and society. Natural, cultural, and environmental attractions abound: the uniqueness of the landscape, the historical value of the small urban centers, and the wealth of traditions linked to the agricultural economy, united by the presence of many archaeological and nuraghic remains. Among the latter, the Nuraghe of Barumini (included in the United Nations Educational, Scientific and Cultural Organization's [UNESCO] list of World Heritage Sites in 1997) is a prime destination in the region of Marmilla, and its draw benefits the whole island of Sardinia. However, tourist groups that visit the Nuraghe often do not consider the island's many other attractions, and so the Nuraghe do not have an appreciable economic impact on the extended area, in terms of employment or stimulating commercial activities.

The municipalities in Marmilla have tried in recent decades to adopt a systematic approach to building a local shared identity, by establishing numerous associations [44]. Government administrators have tried to diversify tourism sites by proposing - unfortunately only on paper - the integration of natural attractions (such as the Geobotanical Park, the Museum of the Territory, and the Jars of Siddi, Collinas, Tuili, and Setzu), with archaeological sites (such as the various archaeological museums and the many areas in which Nuraghes, sacred wells, and the Tombs of Giants are present), and with folkloristic, ethnographic, demo-ethno-anthropological, and historical points of interest (small museums, Romanesque churches, altarpieces from the sixteenth century, cultural centers, festivals and village traditions) [45]. 
In other words, local administrators have not managed to effectively organize a real "team" that could assume responsibility for the formulation of a strategic plan for place-based tourism, using place-based logic to enrich the local community's purely parochial visions. Maybe this is because (temporary) local ambitions promoted place-based identities that did not represent the local community in the best possible light: the area of Marmilla, as mentioned before, has historically been dedicated to agriculture and pastoralism. Not including these aspects in the range of tourist offerings has definitely compromised its place-based, economic, and social development. It is clear that the context for development will not be mass tourism, but rather it will have to consider the interrelationships between sustainability, the local culture, the rural environment, the community, and tourism. The peculiarities of the rural land must remain unchanged, without becoming part of a vicious cycle in which they are sacrificed for economic development.

Other Italian regions (such as Umbria and Marche) have managed to create place-based brands for some areas, and have therefore been able to offer competitive tourism that is linked to the natural characteristics of the agricultural and mountainous sectors.

The typical quality of life in rural areas, the reasonable cost of living, and its central location in Sardinia could combine to make Marmilla a strategic tourist destination, if positive hospitality, commercial, and tourism sector processes are actually implemented.

\subsection{Development of the Tourism Sector in Marmilla}

According to published literature, sustainability has environmental, social, and economic dimensions $[46,47]$. Tourism development is thus sustainable only if has been strategically planned to achieve goals that manifest their effects over the long term. For this reason, Marmilla's strategic programming framework was analyzed at different scales, considering various government instruments such as the Rural Development Programme (RDP) 2014-2020 [48], the Regional Development Plan (RDP) 2014-2019 [49], urban master plans (for all eighteen municipalities), and the spatial strategic plan of Sanluri (the only municipality in Marmilla using this urban tool).

This comparative analysis facilitated the development of a vision for strategic and planned processes in the case study area. It also contributed to an understanding of how best to enhance integrated planning policies for a public/private initiative, and, most importantly, how to requalify rural lands for landscape protection, and for cultural and sustainable rural development (Table 6).

The principles summarized in Table 6 provide insight into how best to orient local communities in Marmilla to these processes. However, the most important innovations for triggering development in this rural area are of two types. These are the region's social capital, and the latest technologies capabilities for raising awareness of the area's rural realities worldwide, and making them attractive for tourists interested in this niche sector.

The local community plays a crucial role in providing sustainable social capital, and must therefore participate in the development process for the long term [50]. Entrepreneurs will be able to increase the area's place-based competitiveness with their innovations [51]. Go, Della Lucia, Trunfio, and Martini (2014) emphasize how important it is to consider social capital under the structural [52], cognitive [53], and relational [54] dimensional perspectives. 
Table 6. Evaluation criteria for redeveloping the area of Marmilla.

\begin{tabular}{|c|c|}
\hline & \\
\hline $\begin{array}{l}\text { ENVIRONMENTAL SUSTAINABILITY; } \\
\text { Preservation of landscapes, habitats, } \\
\text { and ecosystems; } \\
\text { Promotion of the use of } \\
\text { renewable resources; } \\
\text { Introduction or improvement of } \\
\text { environmental management systems; } \\
\text { Protection of the main territorial vocations }\end{array}$ & $\begin{array}{l}\text { LOCAL ECONOMIC DEVELOPMENT; } \\
\text { Encouraging the development of local firms and businesses; } \\
\text { Encouraging the formation of employment } \\
\text { aimed at sustainability of the tourism sector; } \\
\text { Encouraging public and private partnerships; } \\
\text { Promoting the construction or renovation of buildings } \\
\text { for rural tourism, sustainable in the long term, } \\
\text { despite changing political mandates }\end{array}$ \\
\hline $\begin{array}{l}\text { ECONOMIC SUSTAINABILITY; } \\
\text { Development of landscape quality } \\
\text { recognized by international bodies } \\
\text { (UNESCO, etc.); } \\
\text { Development of a market for local } \\
\text { goods and sustainable services; } \\
\text { Encouraging investments in innovative, } \\
\text { environmentally friendly technologies }\end{array}$ & $\begin{array}{l}\text { SUSTAINABLE ENVIRONMENTAL DEVELOPMENT; } \\
\text { Encouraging initiatives dedicated to diversification of } \\
\text { tourism and to the redistribution of tourist flows; } \\
\text { Protecting and promoting the cultural } \\
\text { and historical heritage; } \\
\text { Encouraging the demand for and the achievement } \\
\text { of environmental certification in the tourism sector }\end{array}$ \\
\hline $\begin{array}{l}\text { SOCIAL SUSTAINABILITY; } \\
\text { Triggering processes of awareness } \\
\text { of local tangible and intangible goods; } \\
\text { Activating processes to raise awareness } \\
\text { of the topic of sustainable development, } \\
\text { protection, and enhancement of cultural } \\
\text { heritage and public spaces; } \\
\text { Improving the participatory practices; } \\
\text { Improving the network of relationships } \\
\text { between various stakeholders }\end{array}$ & $\begin{array}{l}\text { SOCIAL DEVELOPMENT; } \\
\text { Developing the integration between different policy sectors; } \\
\text { Construction of participatory practices aimed } \\
\text { at promoting the latest information technology tools } \\
\text { for tourism purposes; } \\
\text { Developing a place-based approach in which } \\
\text { the local community is integrated with tourists; } \\
\text { Promoting opportunities that induce residents to } \\
\text { identify unique regional elements }\end{array}$ \\
\hline
\end{tabular}

For these reasons, particularly in Marmilla there is a need to maintain the area's traditional and historical vocational aspects [55]. Tourists' destination choices in turn may lead to a change of original vocation and increasing competitiveness-but only temporarily (in relation to the structural perspective). It is also important that Marmilla's administrators, including legislators, coordinators, and promoters, start the development process, while conducting their different roles and responsibilities, in line with the dimensional perspective [56]. And finally, the local population's "internal" visions and tourists' "external" visions for a rural place-that constitute the relational dimension of social capital - can help to define a common agenda. In so doing, they will help to identify goals and objectives for developing and promoting the area. For that reason, it is also important to use today's communication and marketing technologies to promote and embed knowledge of the attractiveness of the local area in national and international tourist markets. With regard to the latter point, it will be helpful to identify incentives associated with particular ecological brands recognized by the World Trade Organization (WTO) in the international context such as Ecolabel, or Orange Flag; Organic Farms; Associazione Borghi Autentici d'Italia (The Association of Italian Authentic Villages); and I Borghi più Belli d'Italia (The most Beautiful Villages of Italy), promoted by the National Association of Italian Municipalities (ANCI) in the national context. 
There have been some sporadic adhesions of this type in Marmilla's municipalities. Collinas joined The Association of Italian Authentic Villages. The farm su Massaiu of Turri, which represents an example of excellence at the local level, has joined Ecolabel. In fact, su Massaiu produces a range of local melons, saffron, and a type of grain called Senatore Cappelli. Orchards, olive groves, almonds, medicinal herbs, legumes, and vegetables in general are also cultivated. The farms serve these products to customers or sell them. The benefits of owning such brands are significant. External communications are strengthened by combining the brand's organization (or brand's destination) with the brand's certification, and a virtual path is taken to manage the activities necessary for achieving and maintaining such recognition.

Regarding the second point, using the latest ubiquitous technology to foster, external visibility can do much to leverage development of the Marmilla area, and open the way for innovation, without sacrificing the local cultural and environmental identity. This hypothesis, currently in the concept stage, is further discussed in the following section.

\section{Tourism and New Media, a Possible Combination in Rural Contexts?}

In recent years, global organizations - including the International Council on Monuments and Sites (ICOMOS), UNESCO, and the WTO — have promoted cultural tourism [57], using new technologies [58]. Innovative economic development projects aimed at creating "Smart Regions" [18,19], the application of tools associated with "Neogeography" [20,21], and the development of more integrated and interactive computing platforms [22], have led to many experiments, including some in the field of tourism. Over the last decade, the main innovations in this field have included the creation of specific Internet portals and smart cards, fostering a locale's cultural heritage, and, finally, the diffusion of mobile tourism applications. Technology has allowed the formation of more dynamic and "immersive" relationships between tourists, the area's cultural heritage, and the region [58,59].

Ever-present technology has impacted consumers' demands for vacations, as well as the travel and tour packages being offered by suppliers. It has also enabled the diffusion of tourism information in a manner that has ensured maximum customization and user interaction, in contrast to the influence of traditional paper maps or guidebooks on these activities [59].

With continuing innovations, the information communication technologies (ICT), social networks, and mobile applications can facilitate the integration of tourism products in different moments of the consumption process. They have opened the doors to online marketing, strategic management, and marketing information systems (MkIS). They have changed how tourists search for information on different places and evaluate their alternatives. Service providers can now conduct surveys on tourism behaviors before and after the tourists select a desired destination.

However, in a rural and marginal area such as Marmilla, which is firmly anchored in tradition, the use of technological tools will have to be well understood and supported by the local community if they are to be accepted. These tools appear to be effective when they are accompanied by continuous training for the local communities, thereby creating a self-renewing and reproducing process over time.

In Marmilla then, cultural, rural, and natural excellence needs to be identified, communicated (through various tools, from online to offline dashboards), and systematized, and then used as part of a strategic approach for tourism governance. Porrello (2006) also included cultural planning as an essential 
part of the overall perspective [60]. In Italy, there are sporadic cases in which applications downloadable on smartphones or tablets have been used to promote tourism in rural areas. Of Italian regions, Tuscany has been the most active [61], and even if their communications through digital apps are not organized in an interactive way, they look very similar to website consultations. This mode of technological fruition in rural places is still not widespread in Sardinia. For this reason, the organized and attractive simulation of rural tourism paths that have been realized using the Garau's model $[19,58,59]$ is proposed.

The implementation of rural pathways has led to thinking of whole, place-based involvement, as part of a strategic logic network that will enhance the resources of individual municipalities for the benefit of the whole region of Marmilla. On the basis of the analyses conducted here (Section 3.1), and considering the need to improve social and technological capital (Section 3.2), the author has identified a number of preliminary strategic actions that are linked to the enhancement of the area's cultural and rural heritage, and to the development of sustainable tourism. These actions can be considered as a set of best practices, and a place for local administrators to start, before beginning work on a cultural planning tourism development model.

The recommended actions are listed below:

(1) There is an overarching need to promote sustainable tourism across Marmilla, and not only in the main polarity (for instance what today includes the Nuraghe of Barumini), by highlighting the region's rural and cultural aspects and creating an integrated quality. These aspects include local museums, exhibitions, cultural events, and the interrelation of individual museums associated with rural structures, and interactive educational farms and/or guided tours as part of ongoing rural processes — such as harvesting grain and saffron.

(2) A second required action is developing the skills needed to begin proper planning and programming for rural tourism, through a centralized control, in which experts do not have local interests and are capable of supporting the often fragmentary and conflicting dynamics typical of rural areas. This can be achieved by involving experts who are external to the region.

(3) Next, it will be necessary to enhance local places' competitiveness (for example, by returning to traditional ways of promoting eco-museums, permanent, temporary, or itinerant events, exhibitions, and installations) and entrepreneurial tourism (through prizes or incentives to operators and companies that are distinguished by the quality offered, or through actions that stimulate an increase in the number of beds offered, while basing projects on ethical and sustainable development models).

(4) A fourth action will involve integrating agricultural activities with services that are compatible with tourism activities, by proposing shop windows that display local products.

(5) The visibility of local attractiveness should be unified, by creating a place-based promotion of the entire region of Marmilla (from the establishment of a centralized structure that encourages the formation of networks of rural enterprises, to joint agreement on a unique logo for the area and/or for place-based marketing).

(6) Demand loyalty should be strengthened, through a series of actions aimed at enhancing internal communications among municipalities, and external communications between Marmilla and the rest of the world (for example, launching marketing actions on specific segments; 
promoting new tourism packages; conducting surveys to understand visitors' motivations for coming, enhancing the interest and attractiveness of new offers; improving web marketing actions; promoting seasonal offers; and encouraging the movement of visitors from established attractions to previously unknown places of interest).

(7) Finally, a commitment to sustainability should be used as the parameter for planning tourism in the area. On this point, it is essential that common goals and partnerships among the parties involved be identified, to foster understanding and to periodically update the processes, strategies, and planning associated with tourism development.

These actions, which are summarized in Figure 4, can be merged with the definition of rural pathways for Marmilla's place-based tourism redevelopment. Furthermore, the author has identified ways to enhance the quality and integration of local resources, while on the one hand respecting their historical identity, and on the other hand trying to better understand cultural offerings appropriate for rural tourism. This was achieved by reviewing existing literature on the area's cultural heritage and rural offerings [62-66], and from informal discussions with residents and administrators.

The notion of using different pathways, currently in the concept stage, touches the main points of interest (POIs) with a series of customizable stops that are linked to the availability of opportunities to taste local products, visit the historical, architectural, and archaeological museums representative of Marmilla's widespread heritage, and to visit landscaping, natural, and environmental landmarks and permanent agritourism facilities or educational farms across the region.

The proposal for the pathways is premised on the development of an online platform, downloadable from a smartphone or tablet, but supported by printed materials, and capable of being manipulated by the local community. Media dissemination of mobile technologies could attract people who would not otherwise be aware of Marmilla's potential.

The proposed paths would thus create smart rural-urban linkages, and demonstrate how the planning of and programming for rural tourism cannot escape a comparison with sustainability. Furthermore, in a strategic planning process for the tourism sector, the development of more attractive local organizations could lead to advantages for the whole island, by creating tourism districts for example, and increasing, consequently, the attractiveness of the regional offer [67].

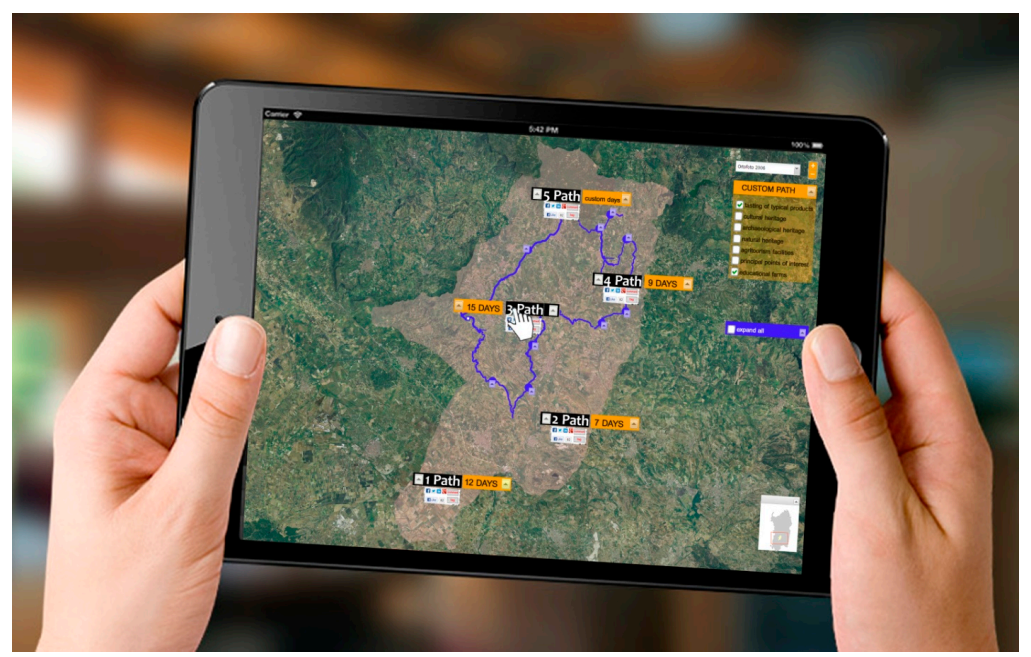

Figure 4. Rural pathways in Marmilla. 


\section{Conclusions}

The challenge that has become apparent by analyzing the Marmilla case study is the need to pursue the goals of place-based improvements, competitiveness, and sustainability in the longer term for this land-locked and marginal area of Sardinia. This perspective-extensible to other national or international rural contexts - is aimed at increasing the number of rural tourist destinations available today, considering the context of Marmilla as a smart tourist destination, and accepting necessary "compromises" between globalization, nature, tourism, places, and people.

As has been discussed, tourism has been used to promote the development of the region of Marmilla by promoting its strengths (the Nuraghe of Barumini), and making improvements that, until now, have been linked to less "traditional" tourist flows. In fact, the Nuraghe of Barumini is a well-known site in the tourism market, but that site alone is unable to trigger new endogenous development across Sardinia.

The integration of the various factors described in this work-such as rural lands, the cultural, archaeological, and natural heritage, local and traditional food production, and networks between all the actors - can constitute a winning tourism offering for tackling the socio-economic issues of rural areas in general, and of the agricultural sector in particular. Tourism structured in this way can trigger collaborative processes among Marmilla's different administrative offices, and thereby initiate actions that will precipitate endogenous development. Namely, they can create the conditions necessary for future developments that include "aggregating tourist offerings", by integrating or diversifying their offerings on the basis of new and different targets such as school tourism, tourism of the third age, religious tourism, and folkloristic tourism.

Strong values consistent with environmental sustainability, and proper diversification of the social fabric and local business community are keys to achieving an essential balance in the case study presented. This vital process must be based on a centralized control that can interface with all the actors, promote their potentialities, and mediate any conflicts. Fragmentary and parochial visions typical of rural areas inevitably lead to heterogeneous approaches to planning and programming tourism products [68]. This difficulty has to be faced and overcome in order to develop tourism products in a time of globalization, when tourists can experience all offerings for a single destination as unique, and cannot be focused on one firm or a single cultural or archaeological product. The image of a destination that emphasizes its vocations and its local cultural heritage is competitive and attractive in itself. It is important to reach the right target, by focusing less on marketing individual products, and emphasizing the uniqueness of the emotional experiences offered.

New forms of communication such as the Internet, social networks, and applications downloadable on smartphones or tablets, such as the one presented in this paper, are essential to improving the visibility and enhancing the promotion of tourism opportunities available in rural Marmilla. However, in this area, where some aspects of a digital divide remain, this form of communication has to be accompanied by formal and informal offline networks. Both modalities of communication are needed to promote the area in the long term, without relying on occasional advertising campaigns. Nevertheless, we must not forget that the successful integration of rural and cultural tourism can be achieved if there is agreement among the various stakeholders-including the local and regional administrators and the local community - to coordinate and encourage the development of local 
resources. They can, in fact, intervene and help the local tourism sector of Marmilla evolve for the better.

\section{Conflicts of Interest}

The author declares no conflict of interest.

\section{References and Notes}

1. McCannell, D. The Tourist: A New Theory of the Leisure Class; University of California Press: Oakland, CA, USA, 1976.

2. Ferrari, C.; Adamo, G.E. Autenticità e risorse locali come attrattive turistiche: Il caso della Calabria. Sinergie 2012, 66, 79-113.

3. Stamboulis, Y.; Skayannis, P. Innovation strategies and technology for experience-based tourism. Tour. Manag. 2003, 24, 35-43.

4. Turco, A. Turismo e Territorialità. Modelli di analisi, strategie comunicative, politiche pubbliche; Unicopli: Milano, Italy, 2012. (In Italian)

5. Hall, D.R.; Roberts, L.; Mitchell, M. New Directions in Rural Tourism; Ashgate: Hants, UK, 2005.

6. Long, P.; Lane, B. Rural tourism development. In Trends in Outdoor Recreation, Leisure and Tourism; Gartner, W.C., Lime, D.W., Eds.; CAB International: Wallingford, UK, 2000; pp. 299-308.

7. European Commission. Community action in the field of tourism. Commission communication to the Council. Bulletin of the European Communities, Supplement 4/86, p. 10. Available online: http://aei.pitt.edu/5410/ (accessed on 21 February 2015).

8. This concept resumes the sustainable development process, in which current needs are satisfied without compromising the needs of future generations (Brundtland Commission. World Commission on Environment and Development Sustainability; Oxford University Press: Oxford, UK, 1987).

9. Simonicca, A. Antropologia del turismo, strategie di ricerca e contesti etnografici; La Nuova Italia Scientifica: Roma, Italy, 1997; pp. 169-173.

10. Daugstad, K. Negotiating landscape in rural tourism. Ann. Tourism Res. 2008, 35, 402-426.

11. Barke, M. Rural tourism in Spain. Int. J. Tour. Res. 2004, 6, 137-149.

12. Lefebvre, H. The right to the city. In Writings on Cities; Kofman, E., Lebas, E., Eds.; Blackwell: Cambridge, MA, USA, 1995; pp. 63-184.

13. Corner, S.; Swarbrooke, J. International Cases in Tourism Management; Butterworth-Heinemann: Oxford, UK, 2004.

14. Cawley, M.; Gillmor, A.D. Integrated rural tourism: Concept and practice. Ann. Tour. Res. 2008, 35, 316-337.

15. Schubert, D. Active regions-shaping rural futures: A model for new rural development in Germany. In Coherence of Agricultural and Rural Development Policies; Diakosavvas, D., Ed.; OECD Publishing: Paris, France, 2006; pp. 333-352.

16. Zhou, L. Online rural destination images: Tourism and rurality. J. Destin. Mark. Manag. 2014, 3, 227-240. 
17. Balestrieri, A.D. Il turismo rurale nello sviluppo territoriale integrato della Toscana; Irpet: Firenze, Italy, 2005.

18. Giffinger, R.; Fertner, C.; Kramar, H.; Kalasek, R.; Pichler-Milanović, N.; Meijers, E. Smart Cities: Ranking of European Medium-Sized Cities; Vienna University of Technology: Vienna, Austria, 2007.

19. Garau, C. Smart paths for advanced management of cultural heritage. Reg. Stud. Reg. Sci. 2014, 1, 286-293.

20. Turner, A. Introduction to Neogeography; O'Reilly: Sebastopol, CA, USA, 2006.

21. Goodchild, M.F. Twenty years of progress: GIScience in 2010. J. Spat. Inf. Sci. 2010, 1, 3-20.

22. Su, K.; Li, J.; Fu, H. Smart city and the applications. In Proceedings of 2011 International Conference on Electronics, Communications and Control, Zhejiang, China, 9-11 September 2011; pp. 1028-1031.

23. Basile, F. Una breve analisi congiunturale del Mezzogiorno nel contesto internazionale e riflessioni preliminari sul settore turistico. In Turismo e territorio: l'impatto economico e territoriale del turismo in Campania; Bencardino, F., Ed.; Franco Angeli: Milano, Italy, 2010; pp. 15-36.

24. Piano strategico per lo sviluppo del turismo in Italia. p. 10. Available online: http://www.agenziademanio.it/export/download/demanio/agenzia/5_Piano_strategico_del_Turism o_2020.pdf (accessed on 21 February 2015).

25. Angeloni, S. Cultural tourism and well-being of the local population in Italy. Theor. Empir. Res. Urban Manag. 2013, 8, 17-31.

26. Musarò, P. Responsible tourism as an agent of sustainable and socially-conscious development: Reflections from the Italian case. Recerca: revista de pensament $i$ anàlisi 2014, 15, 93-107.

27. Sciarelli, S.; Della Corte, V. Il comportamento del turista in condizioni di forte incertezza decisionale. Sinergie rivista di studi e ricerche 2011, 66, 137-152.

28. Paniccia, P.; Vannini, I. Da impresa agricola a agriturismo: un percorso nell'ottica della sostenibilità. In Le imprese nel rilancio competitivo del Made e Service in Italy: settori a confront; Ciappei, C., Padroni, G., Eds.; Franco Angeli: Milano, Italy, 2012; pp. 59-71.

29. Piano strategico per lo sviluppo del turismo in Italia. pp. 5, 30, 47. Available online: http://www.agenziademanio.it/export/download/demanio/agenzia/5_Piano_strategico_del_Turism o_2020.pdf (accessed on 21 February 2015).

30. Santamato, V.R. Turismo e territorio: un rapporto complesso. In Esperienze e casi di turismo sostenibile; Messina, S.; Santamato, V.R., Eds.; Franco Angeli: Milano, Italy, 2012.

31. Istat. Le aziende agrituristiche in Italia 2013. Rapporto aggiornato al 10 ottobre 2014. Available online: http://www.istat.it/it/archivio/133966 (accessed on 21 February 2015).

32. The ISTAT surveys consider only those farms that are treated as such, according to different regional standards. This means that these surveys do not consider those structures that provide the same services but are not incorporated because they are not considered as such by the regional laws.

33. Papotti, D. Marketing territoriale e marketing turistico per la promozione dell'immagine dei luoghi. Rivista Geografica Italiana 2006, 113, 285-306. 
34. Go, F.; Della Lucia, M.; Trunfio, M.; Martini, U. Governing sustainable tourism: European networked rural villages. In Rural Cooperation in Europe: In Search of the "Relational Rurals"; Kasabov, E., Ed.; Palgrave Macmillan: Chennai, India, 2014; p. 163.

35. Puggioni, G.; Atzeni, F. I comuni sardi a rischio di estinzione. In Comuni in estinzione. Gli scenari dello spopolamento in Sardegna; Progetto IDMS-2013; Regione Autonoma Della Sardegna: Cagliari, Italy, 2013; pp. 15-45.

36. Elaborations made by the author on Demoistat Data (2014).

37. Barumini, Collinas, Furtei, Genuri, Gesturi, Las Plassas, Lunamatrona, Pauli Arbarei, Sanluri, Segariu, Setzu, Siddi, Tuili, Turri, Ussaramanna, Villamar, Villanovaforru, and Villanovafranca.

38. Bonifazi, C.; Heins, F. Le dinamiche dei processi di urbanizzazione in Italia e il dualismo Nord-Sud: un'analisi di lungo periodo. Rivista economica del Mezzogiorno 2001, 15, 713-748.

39. Calza, B.P.; Cortese, C.; Violante, A. Interconnessioni tra sviluppo economico e demografico nel declino urbano: il caso di Genova. Argomenti 2010, 29, 105-131.

40. Dematteis, G. Montagna e aree interne nelle politiche di coesione territoriale italiane ed europee. Territorio 2013, 66, 7-15.

41. Author's elaborations on census data from 1861 to 2011. In La popolazione dei comuni sardi dal 1688 al 1991; Angioni, D., Loi, S., Puggioni, G., Eds.; Cuec: Cagliari, Italy, 1997.

42. Author's elaborations on Data DEMO-ISTAT 2014 and on Urbistat's Data. Available online: http://www.urbistat.it (accessed on 21 November 2014).

43. Author's elaborations on Urbistat's Data. Available on: http://www.urbistat.it (accessed on 5 March 2015).

44. For example, the Touristic Consortium of Genna Maria in the municipality of Villanovaforru was the first such association. This story begins in 1969, but was only legally recognized in 1982 because of the lack of agreement among the different municipalities. The Consortium, that later changed its name to Sa Corona Arrubia, then had members from other municipalities. Today there are about twenty members, and almost the same number of museums, as well as thirty-two archaeological areas, and a park's environmental interest. Today Sa Corona Arrubia is having difficulties, although numerous other Consortia (the Consortium of Two Jars; the Consortium of the Natural Park of Monte Arci; and the Consortium Sa Perda e'Iddocca) have joined it over time. All these Consortia are directed and oriented by the Union of Communities of Marmilla, development agencies, and the interprovincial Local Action Groups (LAG) of Marmilla Borgioli C., Deligia M.G., Sa Corona Arrùbia-Consorzio Turistico della Marmilla. Available online: http://sistemimuseali.sns.it/content.php? idSC $=103 \& \mathrm{el}=9 \& \mathrm{c}=106 \& \mathrm{ids}=3 \& \mathrm{o}=$ sistemiCulturali_data InizioInterna\#ds 1 (accessed on 11 May 2015).

45. Sirena, P. Museo Sa Corona Arrubia Museo Naturalistico del Territorio G. Pusceddu. Available online: http://www.sacoronarrubia.it/ (accessed on 4 February 2015).

46. In 2005 the World Tourism Organization (WTO), used the "three pillars" to describe sustainable tourism: "sustainability principles refer to the environmental, economic and socio-cultural aspects of tourism development, and a suitable balance must be established between these three dimensions to guarantee its long-term sustainability". Making Tourism More Sustainable: A Guide for Policy Makers; United Nations World Tourism Organization (UNWTO) and the United Nations Environment Programme (UNEP): Madrid, Spain, 2005; pp. 11-12. 
47. Fons, M.V.S.; Fierro, J.A.M.; y Patiño, M.M. Rural tourism: A sustainable alternative. Appl. Energ. 2011, 88, 551-557.

48. Rural Development Programme (RDP) 2014-2020. Available online: http://www.regione. sardegna.it/speciali/programmasvilupporurale/2014-2020/psr-2014-2020 (accessed on 8 May 2015).

49. Regional Development Plan (RDP) 2014-2019. Available online: http://www.regione.sardegna.it/ $\mathrm{j} / \mathrm{v} / 66 ? \mathrm{~s}=1 \& \mathrm{v}=9 \& \mathrm{c}=27 \& \mathrm{c} 1=1207 \& \mathrm{id}=44429($ accessed on 8 May 2015$)$

50. Belij, M.; Veljković, J.; Pavlović, S. Role of local community in tourism development: Case study village Zabrega. Glasnik Srpskog geografskog drustva 2014, 94, 1-14.

51. Hall, M.C.; Allan, W. Tourism and Innovation; Routledge: London, UK, 2008.

52. "The structural dimension (network ties, configuration and stability) reveals non-hierarchical and dense ties [...]. Community members' relationships are direct, informal, and long-term. There social ties feed and consolidate a strong sense of belonging to the place where these communities live and work and are the base on which inter-member economic ties and knowledge sharing are developed". Go, F.; Della Lucia, M.; Trunfio, M.; Martini, U. Governing Sustainable Tourism: European Networked Rural Villages. In Rural Cooperation in Europe: In Search of the 'Relational Rurals'; Kasabov, E., Ed.; Palgrave Macmillan: Basingstoke, UK, 2014; pp. 173-174.

53. "From a cognitive dimensional perspective, social capital suffers from the fragmentation inherent in the heterogeneity of local stakeholders and sectorial diversification. Diversity of aims, interests, and competence renders the establishment of a critical mass for group decision-making among the local stakeholders difficult. [...] Information and education could help increase the awareness that networked knowledge sharing facilities inclusive economic institution-building and the emergence of a virtuous cycle of value-adding processes". Go, F.; Della Lucia, M.; Trunfio, M.; Martini, U. Governing Sustainable Tourism: European Networked Rural Villages. In Rural Cooperation in Europe: In Search of the 'Relational Rurals'; Kasabov, E., Ed.; Palgrave Macmillan: Basingstoke, UK, 2014; p. 175.

54. "The relational dimension of social capital focuses on the character of connections, which serve to reinforce not only an organisation's internal logic, but also (external) trustworthy relations". Go, F.; Della Lucia, M.; Trunfio, M.; Martini, U. Governing Sustainable Tourism: European Networked Rural Villages. In Rural Cooperation in Europe: In Search of the 'Relational Rurals'; Kasabov, E., Ed.; Palgrave Macmillan: Basingstoke, UK, 2014; p. 176.

55. Nasser, N. Planning for urban heritage places: Reconciling conservation, tourism, and sustainable development. J. Plan. Lit.2003, 17, 467-479.

56. Weaver, D.B. Tourism and the elusive paradigm of sustainable development. In A Companion to Tourism; Lew, A.A., Hall, C.M., Williams, A.M., Eds.; Backwell: Oxford, UK, 2004; pp. 510-524.

57. Law, R.; Leung, R.; Buhalis, D. Information technology applications in hospitality and tourism: A review of publications from 2005 to 2007. J. Travel Tour. Market. 2009, 26, 599-623.

58. Garau, C.; Ilardi, E. The "Non-Places" Meet the "Places:" Virtual Tours on Smartphones for the Enhancement of Cultural Heritage. J. Urban Tech. 2014, 21, 79-91.

59. Garau, C. From Territory to Smartphone: Smart Fruition of Cultural Heritage for Dynamic Tourism Development. Plan. Pract. Res. 2014, 29, 238-255. 
60. According to Porrello, cultural planning enhances the totality of cultural, environmental, and naturalistic goods by taking strategic actions that are in line with the economic and social sustainability of the local context under study. Porrello, A. L'arte Difficile del Cultural Planning; Grafiche Veneziane: Venice, Italy, 2006. Avaliable online: http://www.iuav.it/Ateneo1/docenti/ pianificaz/docenti-st/Antonino-P/materiali-/Cultural_Planning.pdf (accessed on 11 March 2015).

61. Below are some examples. Available online: http://www.turismo.intoscana.it/site/it/ itinerario/Sei-un-turista-rurale/ and http:/www.iAGRITURISMO.it. This last link in particular allows users to view the portal of Italian Farms in i-mode, with any type of mobile phone. Here too, the Tuscany region ranks high in the number of farmhouses present.

62. Mistretta, P. Beni Culturali e sistema territorio. ArcheoArte 2012, 1, 11-19.

63. Mureddu, D.; Murru, G. Alla scoperta dei monumenti della Marmilla: Archeologia, arte, architettura; CRES: Cagliari, Italy, 2000.

64. Lilliu, G. La civiltà dei Sardi dal paleolitico all'età dei nuraghi, (Vol. 98); Nuova Eri: Torino, Italy, 1988.

65. Atzeni, C., Ed. I manuali delle colline e degli altipiani centro-meridionali, Tipografia del Genio Civile: Roma, Italy, 2009.

66. Atzeni, C., Sanna, A., Eds. Architettura in terra cruda; Tipografia del Genio Civile: Roma, Italy, 2009.

67. Purpura, A.; Ruggieri, G. Il distretto turistico: Caratteristiche e modelli organizzativi. In I distretti turistici: Strumento di sviluppo dei territori. L'esperienza nella regione Sicilia Milano; Cusimano, G., Parroco, A.M., Purpura, A., Eds.; Franco Angeli: Milan, Italy, 2014; pp. 19-41.

68. McAreavey, R.; McDonagh, J. Sustainable rural tourism: Lessons for rural development. Sociologia ruralis 2011, 51, 175-194.

(C) 2015 by the author; licensee MDPI, Basel, Switzerland. This article is an open access article distributed under the terms and conditions of the Creative Commons Attribution license (http://creativecommons.org/licenses/by/4.0/). 